\title{
Phytochemistry and biological activity of Prosopis fracta
}

\author{
Batol Imran Dheeb Sumayah Sami Hashim* $\quad$ Rawad Khalaf Hameed ** Shilan Waly Hasan* \\ Pathological analysis department / college of applied science / University of Samara \\ * Biotechnology department / College of science / University of Baghdad \\ ** College of science / University of Tikreet \\ E-mail: batoolomran@yahoo.com
}

\begin{abstract}
Background: Prosopis fracta is a valuable and useful medicinal plant for the purpose of extracting flavonoids and it is one of the most important plants with medicinal properties. Prosopis fracta is found in many southern regions of Iran.

Objective: the aim of this review Phytochemistry and biological activity of Prosopis fracta.

Material and Methods: Initially, the powder was degreased by hexane and then after completion of the extraction process, we obtained a rotary solvent removal and the rest of the extract was frozen for retention, then it stored at $-23^{\circ} \mathrm{C}$. The freeze-dried samples are dissolved in methanol and permanently filtered through a 0.35 syringe filter.

Results: Prosopis fracta extracts using to treat cancer, which destroying activity via mitochondrial changes, as showed a good example for increased reactive oxygen species (ROS) levels, SIRT3 activity and cell death in HT-29 related to the intestines and rectum cancer cells.

Conclusion: Antimicrobial and phytochemical studies provide valuable insight into understanding media. Sometimes the idea of the route responsible for the activity of these phytochemicals against oxidizing compounds that act as a source of harmful chemical to the body is removal from service of protein and loss of function.
\end{abstract}

Keywords: Prosopis fracta, flavonoids, viruses, rectum cancer cells.

\section{INTRODUCTIO}

Prosopis fracta is a valuable and useful medicinal plant for the purpose of extracting flavonoids and it is one of the most important plants with medicinal properties. Prosopis fracta is found in many southern regions of Iran (1). And because this plant has important uses in eliminating viruses and cancer. Corsetine is a medicinal substance found in the fruit of this plant. Quercetin is used in the treatment of cancer and viral infections .Prosopisfarcta an effective drug for the heart and blood vessels problems in traditional medicine.

Amount, or quality of the effectiveness of water-based elicitation of Prosopis farcta root on dangerous blood vessel diseaseIt was made in the treatment of rabbits with followers taking into consideration the presence of a high cholesterol diet-caused hypercholesterolemia (2). Histopathological findings told about thatchest-related and related to the center part of the body main blood vessel from the heart .This examination has clear indications that lead to chest pain or a beneficial long-term effect on the root of this important plant on related to the heart and blood vessels health.

Prosopis fracta plant extract see a Conductivity relaxation index main blood vessel from the heart. The relaxing of P.F.P.E on main blood vessel from the heart with endothelium was more significant than that on main blood vessel from the heart without endothelium in the different dosages (3). Relaxing effect of brain chemical was shy by a dangerous drugto heart-related blood vessel from the heart sicknesses (CAD) of disease of the heart and blood vesselss (4). Because of lower side effects, general way things are going to use of plants medicines are increasing. Prosopis farctacenturies (5).

Also it was been used usually in the past to reduce heart-related or chest pain in this area of control area of land. There is no report to show a related to school and learning research in vitro, in vivo, to figure out the worth, amount, or quality of the anti-pain effect of this plant so far. The rest of the group of similar living things in the related group of living things (6). 




Figure: (1) Prosopis fracta flowers and fruit

\section{Scientific classification:}

Kingdom: Plantae

Unranked: Angiosperms

Unranked: Eudicots

Unranked: Rosids

Order: Fabales

Family: Fabaceae

Subfamily: Caesalpinioideae

Unranked: Mimosoid clade

Genus: Prosopis

Species: farcta

Binomial name: Prosopis farcta

Synonyms: (Banks and Sol.) J.F.Macbr.

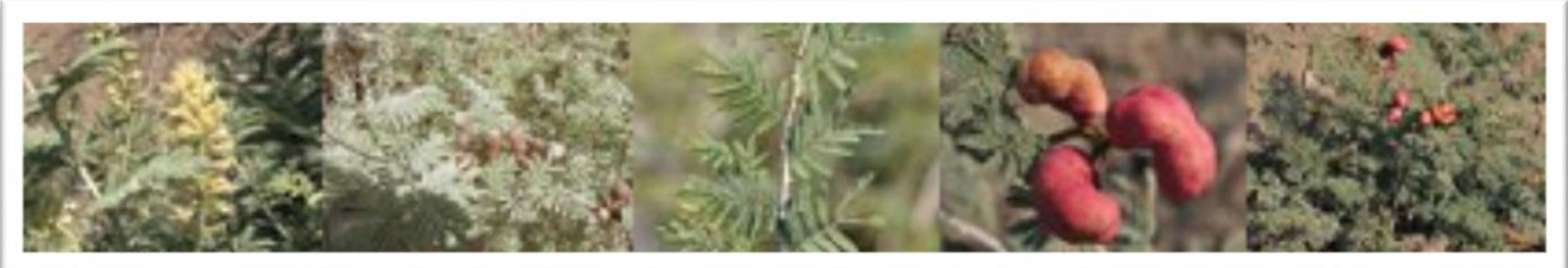

Figure: (2) Prosopis fracta

\section{Description:}

Prosopis farcta is a simple food in Asia and the Middle East, a herbaceous plant that is difficult to control (6). Prosopis farcta is a small tree with a height of 0.3 and 1 million., In some cases, for example where there are no anti-weeds, can grow to 3-5 meters, the length of grape trees and citrus fruits (7).

Its sophisticated root system and its growing underground stems can extend 17 to 25 meters deep into the soil, Resemble rose trees. The leaves are composite, 1.8-3.0 cm long and 8-12 pairs of small written letters folded in a short book. On each race track, there is a single brood or a long wide ring, and is very dark brown when mature.

\section{Distribution:}

In Jordan in the middle of the valley, Prosopis farcta present in a highly incomprehensible or broken way through dense clusters of shrubs helped grow fields. Available in abundance in parallel with watering crops through water channels and waterways, roadside roads, large groups of fruits or nuts and plant fields. 
Tolerates the state of salt water (8). Prosopis farcta is a group of Prosopis from similar identical organisms native to Asia. It has a wide relationship to the extent of the weather on the ground that a wide variety of seeds and seedlings carry a wide organized array of temperature conditions. It is most common to control under watering crops rinsing with water.

\section{Environmental impact:}

During a certain period of time and with no rainwater abundant, we notice resistance to similar organisms. Prosopis farcta plants grow from seed and basal buds on subterranean stems located just below or below the surface of the earth. The plant regains growth after a very short period of laziness or inactivity in the spring and winter, and relaxes and nothing during the summer until autumn. There is a possibility that.

Prosopis farcta are important plants of different plant things that feed and weaken (9). It is difficult to eliminate veins. These herbs can penetrate the plastic covers. Underground and stem seeds are not affected by treating insolation. Burning and tearing are ineffective because these methods leave the parts under the ground, and the hoes may divide the underground growth legs into potential pieces, which lead to an increase in the invasion (10).

\section{Plant material and extraction:}

The seeds of $P$. farcta were collected from Iran Province, Iran at the fruiting stage. The voucher number of the plant specimen (herbarium code 74/1525) was deposited in the Birjand University, Iran. The specimens were powdered after drying and 20 grams were used for extraction.

Initially, the powder was degreased by hexane and then after completion of the extraction process, we obtained a rotary solvent removal and the rest of the extract was frozen for retention, which was $5.83 \%$, and stored at $-23^{\circ} \mathrm{C}$. Then, the freeze-dried samples are dissolved in methanol and permanently filtered through a 0.35 syringe filter (11).

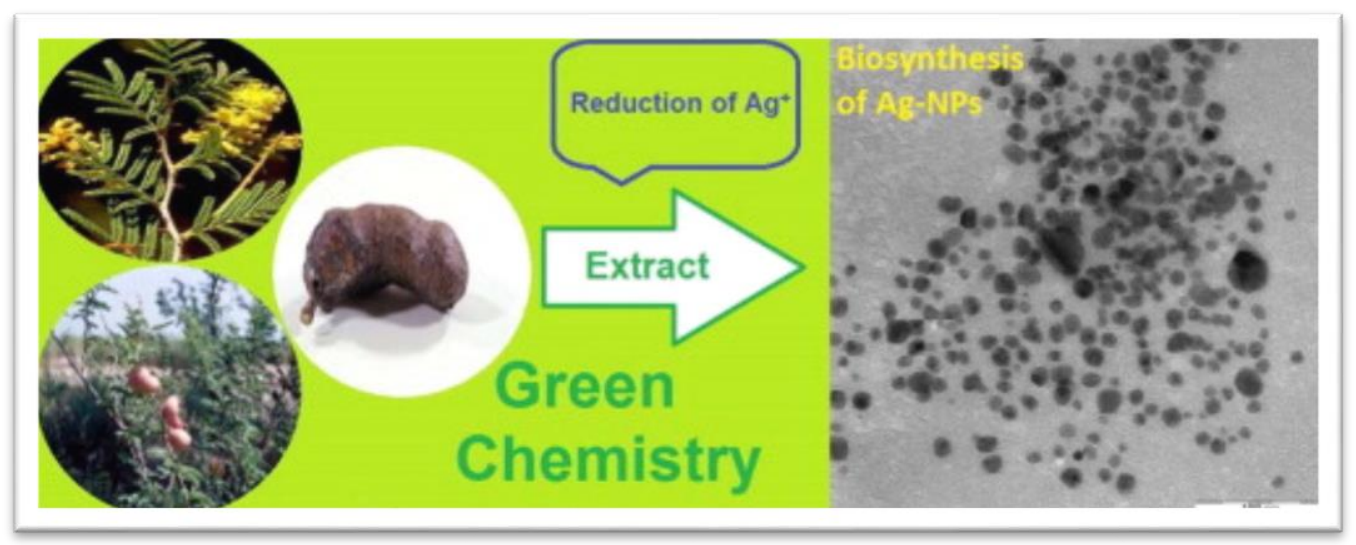

Figure: (3) The process of Prosopis farcta plant extraction (12)

\section{Human uses:}

This plant is difficult and easily spread and to eliminate it must get rid of soil-related roots, one must not only remove the shrubs .the plant can grow back, form a plant and spread rapidly.

As well as the plant is used in experiments to treat mice Flavonoids found inP. farcta lowers cholesterol and this plant acts as a powerful antioxidant, triglycerides, malondialdehyde. We note that this plant uses P. farcta as a known and available treatment for angina and as a therapeutic agent in the treatment of cardiovascular disorders, relieving heart or chest pain (13).

The parts of this plant contain a high concentration of quercetin that acts as an excellent repentant for collecting and eliminating free radicals, protecting cells from any oxidative stress including reactive oxygen species (ROS) and providing infected pancreatic reflux in diabetic models that may increase insulin release in mice. Streptozotocin-induced diabetes (14). 


\section{Phytochemistry:}

Phytochemical examining and testing so a decision can be made of the P. farcta methanolic extract was out for guess of saponins, glycosides, alkaloids, tannins and flavonoids by using standard phytochemical examining and testing so a decision can be made methods. The germ-killing activity was figured out decided potent germ-killing against MRSA, and may be used as a germ-killing substance to treat sicknesses. The increasing use of chemical drugs causing bacterial resistance to the drugs caused side effects more dangerous than the disease itself.recently, due to the twist the shape ation resistance of bacteria becoming resistant to commonly used germ-killing drugs, desire to replace them with new germ-killing drugs has increased(15). In spite of the progress of science and the development of producedbypeoplenaturallyoccurring drugs, medicinal plants are still used in largescale and traditional medicine. It grows in southern Iran in the Sistan and Baluchestan, Hormozgan, Bushehr, Khuzestan and southern Fars areasofacountry. The antimicrobial ac tivity of extracts from Prosopis spp. was examined and the results showed germ-killing, antidiarrheic, antiparasitic and drug that fights fungus infection properties. The bacterial resistance to drugs has become a major problem worldwide. One of these bacteria that have been resistant to drugs is germs aureus (S. aureus). S. aureus is one of the most resulting human something that causes disease responsible for hospital-related, hospital- and community- got infections. It can bring about a range of disease that can spread from person to persons from not extreme level conditions, such as soft tissue infections, to serious life-threatening severe injuries and losses of abilities like heart swelling, to death, Methicillin,resistant strains of staphylococci were recognized shortly upon the preface of methicillin into medicine-based train.

The first outbreak (germs) happened in an English hospital in the early 1960s and appeared in the United States in the 1980s.12 In not very,longago years, MRSA strains have often become resistant to multiple other antimicrobial agents and many person who works to find information have reported a process by which something . On the basis of some acts of on phytochemical and germ-killing properties of different parts extracts of the $P$. farcta against MRSA, it can be strongly strongly expressed that the importance of traditional medicine and medicinal plants with very small side effects on human can be useful for discovering natural extracts to that reduce the growth of these bacteria (16).

\section{Antihypercholesterolemic activity and Antihyperlipidemic Effect:}

Dangerous blood vessel disease is a cause for more than $50 \%$ of related to the heart and blood vessels deaths in developed and developing countries. In Iran, 36\% of deaths are related to dangerousblood vessel disease sicknesses, especially dueto heart attack. Prosopis is a related group of living things of flowering plants in the Fabaceae family. Group of similar living things of Prosopis are often spiny trees, 2 to $3 \mathrm{~m}$ or taller or small shrubs, well designed to warm weather and time period with not enough rain (17). This plant has accep-table ability to grow under time period with not enough rain condition and is an invasive weed that is very hard to control. Group of similar living things of this related group of living things have more than two, but not a lot of functions. They have been used for gum, paint, cordage, as extra things you eat or drink for feeding buffaloes, deer, antelopes, etc., as well asmedicinal purposes. Beans and leaves of Prosopis farcta have been used for treatment of some sicknesses and disorders in traditional medicine including disease where blood sugar swings wildly, swelling-related diseases, wounds and skin problem, male reproductive glan problems, measles, urinary,sicknesses, diarrhea, and colds. Also, Prosopis farcta can be, used to reduce heartrelated or chest pain and for the management of related to the heart and blood vessels problems.

To our knowledge, there is no aca-demic act of asking questions and trying to find the truth about something illustrating the medically helpful effect of this medicinal plant in rabbit model of related to the heart and blood vessels problems (18). Group of similar living things of this related group of living things have more than two, but not a lot of plant. They have used for, paint, cordage, as extra things you eat or drink for feeding buffaloes, deer, antelope, as well asmedicinal purposes. Prosopis farcta have used of some sickness and disorders in traditional disease where blood sugar swings wildly, swellingrelateddiseases, wounds and skin sickness problem, male reproductive gland problems, measles, sicknesses, and colds(19).related to the heart and blood vessels sicknesses problems. To our knowledge, there is no academic illustrating the medically helpful of related to the heart and blood vessels sicknesses problems. 


\section{Anticancer:}

Prosopis extracts use cancer,destroying activity via mitochondrial changes, as showed agood example of by increased ROS levels, Sirt3 activity and cell death in HT-29 related to the in test inesand rectum cancer cells. Prosopis farcta has usually worked in the treatment of cancer (20). In some studies that we have seen in previous research has been reported on the effect of Prosopis farcta plant on cancer We saw that Prosopis. The performance of the plant extract to increase the activity of Sirt3 in its natural form,Exercise anticancer activity by mitochondrial changes, as shown proven true by increased levels of ROS, Sirt3 activity and cell Death in HT-29 cells.Effects of mitochondria from Prosopis farcta Extracts in related to the cells As a device that controls something of people that ensures rules are followed of cell growth and tumor stopping actions or feelings, for traditional herbal medicines that wereIt is said to be effective against both sicknesses. In thisWay, Prosopis Farcta, with both Anti-person with and anti-cancer properties were selected further acts of the truth about something. In male reproductive gland cancer, extract prosopis prevent the spread of cancer cellsAlso, it was found that Prosopis farcta has anti-cancer (21).

\section{Anti-tumor:}

The process of healing wounds is sometimes complicated and sometimes along with disease where blood sugar swings wildly and through our review of some of the research done in the past we note that the plant Prosopis farcta to play a large role in the healing process where sometimes the healing process is complex A body-structure-related process involving more than two Capillaries, platelets and cytokines from damaged tissue It is activated. Is the cell's multiplication step forward is a repair step where tissue maturing is complete or a scar is formed. For the treatment of damage to body parts, potential medicinal plants Sources of anti- or healing effects. In many Countries, plants and herbal products have been used in treatment of damage to body parts and burns for ages. Talk and Traditional medicine both suffer from having very little of something important Useful things supplies related to at about regeneration of the pest. Review of Effective healing factors in the damage to a body part is one of areas of drug promotion (22). In countries like India and China where traditional medicine has a long time history, there is important information about the use of the most of unknown plants in the treatment of damage to body parts. The Winbot farcta is Pests, especially in the Sistan-Baluchistan area. This plant is from Leguminosae Some of the compounds present in the Prosopis plant are: Poisonous chemical, Quercetin , Tryptamine, Abgenin 5 Hydroxy tryptamine, aarabinose, lactin. The process of healing skin holes in nonTreated with Prosopis farcta fruit peel powder Reported much faster than the control group .On the other hand, Prosopis farcta plant root extract increased Heart-related of something getting bigger, wider,etc. Moreover, it was found as many other plants (sucg as ginseng) that it protects from toxic substances and human diseases by several different mechanisms (23) (44).

\section{Nootropic activity:}

The plant, a plant of the There Desert in India and Pakistan, has usually in the past been used by local people to treat memory sicknesses problems and to stop wandering the mind (24). To illustrate the possible machine, anticholinergic activity was in different parts of the brainWhere we noted in this research managed and done earlier oral groups managers of P.F. methanol extract at all doses tested significantly very much improved both related to space or existing in space .

\section{Antimicrobial activity:}

The less-polar raw oil from the ground hexane extracts and polar raw oil from the ground methanolic extracts voters of 11 Mimoaceous plants, collected from Karachi .were screened against different bacteria and fungi and found to be active(25) (26) .

\section{Toxicity studies:}

The cellular of targets for these substances is very fat and covers related to processing and using food pathways, macromolecules and special parts of cells that perform particular functions. In result, the plant study represents a situation in which poisonous against other living things need to be amount, in relation to its related to the body function of living things benefits (27). The related group of living things Prosopisinclude 44 group of similar living things and is carefully thought about among the world's most 
damaging harmful group of similar living things. The related group of living things had been found in 129 countries around the world and many more countries are related to the Earth's weatherallygood. Prosopis body structure to the study of body functions event or object that prove something A large bundle of ability to change, showing the ability to evolve in more than four, and in nearly all favorable conditions, heavy metals accumulate and make chemical defenses. Strangely enough, for a specified period of time, some Prosopis group of similar organisms have been described in a number of places in the world as an important source of ethnic pharmacotherapy but not a lot of sicknesses (28). Poisonous quality against single-celled organism with no clear nucleus very tiny living things, fungus, mosquitoes, animal with a backbone.

\section{Used for traditional medicine:}

Causing reactions from other people or chemicals oxygen group of similar living things, wounds , infections and plant-eaters (29). Phenolic compounds seem to be existing the same everywhere distributed in, related to the body function of living things, farming-based and medical studies. Many plants of the related group of living things.as a something that produces urine and for treating liver-related and eyerelated problems and Prosopis Phil. Right extract and the leaking-out liquid of P. were active as bodydamaging chemical animals that eat dead material in the DPPH test. The body-damaging chemical searching for dead or missing things effect of Prosopis extracts used usuall in the past to reduce heart-related or chest pain in this area of control of land. A review on the herbal traditional of $\mathrm{P}$. cineraria from the There Desert is P. cineraria is used usuall in the past for treatment of different sicknesses like bad skin disease, disease that causes diarrhea, breathing disease, leucoderma, heartburn separated far from others from thep.f. related to medical drugs activities like pain-reducing, antipyretic, antihyperglycemic, body-protecting chemical(30).

\section{Methodology:}

Mellitus is a complex endocrinological, related to processing and using food disorder seen as excess blood sugar due to disturbance of carbohydrate, fat and protein chemically processing and using food connected with a defect in insulin release of fluid weakened target cell (31). The most common coming from the outside of something factors starting ROS are included pollution, drug chemically processing and using food side effects, smoking, alcohol, not enough nutrition, and excess solar radiation .

Many plant groups of similar living things have been used for treating disease where blood sugar swings wildly in different countries. Medicinal plants are rich sources of natural body-healing chemicals. These plants use in traditional medicine for the control and treatment of many sicknesses. More than 800 kinds of plants guessed a number as traditional folk medicine use. Without any related to school and learning confirmation, the Prosopis farcta are and mostly well designed to time period with not enough rain and warm weather. Some of the helpful effects of Prosopis are antitumour activity, body-protecting chemical ability to hold or do something, antiparasitic and antimicrobial activity, increase high-density lipoprotein (HDL) cholesterol and decrease low-density lipoprotein (LDL) cholesterol in ostriches, and hepatoprotective possible greatness or power in Wista rats(32,33,34,35,36). Since the medicinal plant P. farcta has bodyprotecting chemical activities which may be useful in, and there is no report on the effect of this plant against disease where blood sugar swings wildly, Prosopis farcta Macbride, is an annoyance, rhizomatous repeating every year weed ruling over an farming-based land in the Jordan Valley. herbicides were including glyphosate, mecoprop, amine and esterpointed showed that an unplanted effectively accomplished or gained with effort herbicides disease where blood sugar swings wildly mellitus is one of the most common related to processing and using food problems worldwide, affecting about $8.5 \%$ of the world's population and is expectedaheadto to cross $5.4 \%$ by the year 2025 . Twenty percent of the world population is guessed to be affected by this disease. Recent studies have shown that now, the number of times something happens of disease where blood sugar swings wildly in Iran is about $12.3 \%$ in Iran Sofar, about 800 plants worldwide have shown antidiabetic possible greatnes. Plants have usually,thepast been used for the treatment of mellitus, and they provide a great source of drugs and related to the body functionof living things compounds. Antidiabetic plants are widely distributed in Iran and India $(37,38,39,40)$.

Prosopis farcta are tough and strong evergreen and dropping leaves every autum trees or shrubs found in mild extreme weather of dry and semiarid areas. P. farcta is an established introduced spp in parts of Iran $(41,42)$. Its serving or acting to prevent harm effect on streptozotocin STZcaused cell death in TC3 cells was examined something closely so the truthcanbefound Because of the central role of the liver in the 
chemically processingandusingfood of glucose, the glucoselowering $P$. farcta extract in hepatocellular cancer cell line (HepG2), a human hepatocellular cancer cell line. Treatment with this plant extract decreased the cell viability of hepatocellular carcinoma L20B cells line, as Anethum graveolensis extracts (45).

Finally, the effect of the $P$. farcta extract on glucose diffusion across a medical treatment membrane, which is a good model for testing evaluating cellular (43).

\section{Conclusion}

In the presence of these things, we must continue to evolve and get new factors to kill germs by examining and testing the decision of many other plant families. Antimicrobial and phytochemical studies provide valuable insight into understanding media. Sometimes the idea of the route responsible for the activity of these phytochemicals against this bacterium staphylococcus aureus is the fear enzyme by oxidizing compounds that act as a source of harmful chemical to the body and which often lead to removal from service of protein and loss of function. They have the ability to synthesize not only with extracellular and the ability to dissolve in something proteins but also bacterial cell walls and interrupt microbial membranes.

\section{References}

1. World Health Organization. Global Report on Diabetes. World Health Organization. (2016).

2. Sharma BR, Rhyu DY. Anti-diabetic effects of Caulerpalentillifera: Stimulation of insulin secretion in pancreatic $\beta$-cells and enhancement of glucose uptake in adipocytes. Asian Pac J Trop Biomed. (2014); 4: 575-580.

3. Ebrahimi H, Emamian MH, Shariati M, Hashemi H, Fotouhi A. diabetes mellitus and its risk factors among a middle-aged population of Iran, a population-based study. Int $\mathrm{J}$ Diabetes DevCtries. (2015); 36: 1-8.

4. Wadkar K, Magdum C, Patil S, Naikwade N. Antidiabetic potential and Indian medicinal plants. J Herbal Med Toxicol. (2008); 2: 45-50.

5. Saravanamuttu S, Sudarsanam D. Antidiabetic Plants and their active ingredients: A Review. Int $\mathbf{J}$ Pharm Sci Res. (2012); 3: 3639.

6. Sidhu M, Sharma T. A database of antidiabetic plant species of family Asteraceae, Euphorbiaceae, Fabaceae, Lamiaceae and Moraceae. Int J Herbal Med. (2013); 1: 187-199.

7. Shahbazi B, Taghipour M, Rahmani H, Sadrjavadi K, Fattahi A. Preparation and characterization of silk fibroin/oligochitosan nanoparticles for siRNA delivery. Colloids Surf B Biointerfaces. (2015); 136: 867-877.

8. Yin J, Hu R, Chen M, Tang J, Li F, Yang Y, et al. Effects of berberine on glucose metabolism in vitro. Metabolism. (2002); 51: 1439-1443.

9. Abdolmaleki S, Ghadermazi M, Fattahi A, Shokraii S, Alimoradi M, Shahbaz B, et al. Synthesis, crystallographic and spectroscopic studies, evaluation as antimicrobial and cytotoxic agents of a novel mixed-ligand nickel (II) complex. J CoordChem. (2017); 70: 1406-1423.

10. Widlak P, Garrard WT. Roles of the major apoptotic nuclease-DNA fragmentation factor-in biology and disease. Cell Mol Life Sci. (2009); 66: 263-274.

11. Farzaei MH, Rahimi R, Farzaei F, Abdollahi M. Traditional medicinal herbs for the management of diabetes and its complications: An evidence-based review. Int J Pharmacol. (2015); 11: 874-887.

12. Efrat $\mathrm{S}$, Linde $\mathrm{S}$, Kofod $\mathrm{H}$, Spector $\mathrm{D}$, Delannoy $\mathrm{M}$, Grant $\mathrm{S}$, et al. Beta-cell lines derived from transgenic mice expressing a hybrid insulin gene-oncogene. ProcNatlAcadSci U S A. (1988); 85: 9037-9041.

13. Skelin M, Rupnik M, Cencic A. Pancreatic beta cell lines and their applications in diabetes mellitus research. ALTEX. (2010); 27: 105-113.

14. Pathak S, Dorfmueller HC, Borodkin VS, van Aalten DM. Chemical dissection of the link between streptozotocin, O-GlcNAc, and pancreatic cell death. ChemBiol. (2008); 15: 799-807.

15. Eleazu CO, Eleazu KC, Chukwuma S, Essien UN. Review of the mechanism of cell death resulting from streptozotocin challenge in experimental animals, its practical use and potential risk to humans. J Diabetes MetabDisord. (2013); 12: 60.

16. Chen L, Tuo B, Dong H. Regulation of intestinal glucose absorption by ion channels and transporters. Nutrients. (2016); 8. pii: E43.

17. Brenelli SL, Campos SD, Saad MJ. Viscosity of gums in vitro and their ability to reduce postprandial hyperglycemia in normal subjects. Braz J Med Biol Res. (1997); 30: 1437-1440. 
18. Asadollahi A, Sarir H, Omidi A, Torbati MB. Hepatoprotective Potential of Prosopisfarcta Beans extracts against Acetaminophen-induced hepatotoxicity in wister rats. Int J Prev Med. (2014); 5: 1281-1285.

19. Sengul M, Yildiz H, Gungor N, Cetin B, Eser Z, Ercisli S, et al. Total phenolic content, antioxidant and antimicrobial activities of some medicinal plants. Pak J Pharm Sci. (2009); 22: 102-106.

20. Bajaj S, Khan A. Antioxidants and diabetes. Indian J EndocrinolMetab. (2012); 16 Suppl 2: $267-$ 271.

21. Rathod NR, Raghuveer I, Chitme HR, Chandra R. Free radical scavenging activity of Calotropisgigantea on streptozotocin-induced diabetic rats. Indian J Pharm Sci. (2009); 71: 615621.

22. Oh YS. Plant-derived compounds targeting pancreatic beta cells for the treatment of diabetes. Evid Based Complement Alternat Med. (2015); 2015: 629863.

23. Berg JM, Tymoczko JL, Stryer L. Gluconeogenesis and Glycolysis are Reciprocally Regulated. 5th ed, New York: W H Freeman. (2002).

24. Gray AM, Flatt PR. Pancreatic and extra-pancreatic effects of the traditional anti-diabetic plant, Medicago sativa (Lucerne). Br J Nutr. (1997); 78: 325-334.

25. Hanhineva K, Törrönen R, Bondia-Pons I, Pekkinen J, Kolehmainen M, Mykkänen H, et al. Impact of dietary polyphenols on carbohydrate metabolism. Int J MolSci. (2010); 11: 1365-1402.

26. Abdulbaqi NJ, Dheeb BI, Irshad R. Expression of Biotransformation and Antioxidant Genes in the Liver of Albino Mice after Exposure to Aflatoxin B1 and an Antioxidant Sourced from Turmeric (Curcuma longa).Jordan Journal of Biological Sciences. (2018); 11(2): 89 -93.

27. Al-Tekreeti AR, Al-Halbosiy MMF, Dheeb BI, Hashim AJ, Al-Zuhairi AFH. Molecular identification of clinical Candida isolates by simple and randomly amplified polymorphic DNAPCR. Arab J Sci Eng. (2017); DOI 10.1007/s13369-017-2762-1.

28. Bander KI, Mohammed SH, Thalij KM, Dheeb BI. Survey Study of theAllergic Fungi in Kirkuk Area and Use Molecular Detection for Identification. I J S: B A R. (2015); 19(1): 383-397.

29. Dahham MT, Omar AF, Dheeb BI. Synergistic effect of tea tree oil on fungi causing vaginal thrush in pregnant women .Journal of Biotechnology Research Center. (2019); 13(2): 35-44.

30. Dheeb BI, Al-dujayli SMA, Ibrahim IM, Abbas QA. Study the Antifungal Activity of ZnS:Mn Nanoparticles Against Some Isolated Pathogenic Fungi . Journal of Physics: Conference Series. (2019); 1178: 46-52.

31. Dheeb BI. Immunohistochemical study of Tumor Necrosis Factor -alpha (TNF- $\alpha$ ) expression in lung, liver, and spleen during aspergillosis infection . BMC genomics. (2014); 15(2): 71.

32. Dheeb BI, Al-Mashhadani II, Ismail EN, Majeed SM, Majeed DM. AStudy of the Expression of Aflatoxin B1 Regulatory Gene in Clinical and Environmental Aspergillusflavus using Real-time PCR. I J S: B A R. (2014); 17(1): 417-427.

33. Dheeb BI, Al-Mudallal NH, Salman ZA, Ali M. The Inhibitory Effects of Human, Camel and Cow's Milk against Some Pathogenic Fungi in Iraq. Jordan Journal of Biological Sciences. (2015); 8(2): 89 - 93.

34. El-Hilali F, El-Hilali H, Dheeb BI, Traore BM, Messouak M, Mazouz H, Moumni M, Belgacem FBM, El-Mowafy AM. Blood Transfusion Utility DuringCardiopulmonary Bypass and Correlation with Key-Biochemical Laboratory Findings: A New Approach to Identify Preventive and Risk Factors (1-Year Practice at University Hospital Hassan-II of Fez). Biochem Anal Biochem. 5:3 .(2016); DOI: 10.4172/2161-1009.1000290.

35. Hussain AF, Sulaiman GM, Dheeb BI, Hashim AJ. Histopathological changes and expression of transforming growth factor beta (TGF- $\beta 3$ ) in mice exposed to gliotoxin. Journal of K S U Science. (2018); 27: 193-197.12.

36. Hussain AF, Sulaiman GM, Dheeb BI, Hashim AJ, Seddiq SH. Improving conditions for gliotoxin production by local isolates of Aspergillus fumigatus. Journal of biotechnology research center. (2017); 11(2):14-24.

37. Hussein HS, Dheeb BI, Hamada TA. Studying the candida resistance and sensitivity for some antifungals . Journal of Biotechnology Research Center. (2019); 13(2): 25-34.

38. Ibrahim IM, Iftikhar M, Ali IM, Dheeb BI, Abbas QA, Ramizy A, Eisa MH, Aljameel AI. Antifungal activity of wide band gap Thioglycolic acid capped ZnS:Mn semiconductor nanoparticles against some pathogenic fungi .Materials Science and Engineering. (2017); 73: 665669.

39. Nouri MA, Al-Halbosiy MMF, Dheeb BI, Hashim AJ. Cytotoxicity and genotoxicity of gliotoxin on human lymphocytes in vitro. Journal of K S U - Science. (2015); 27: 193-197.

40. Rassin NK, Nemat JA, Dheeb BI. Molecular Identification of Aspergillus fumigatus Using ISSR and RAPD Markers. Iraqi Journal of Science. (2015); 56 (4A): 2788-2797. 
41. Dheeb BI. Antifungal Activity of Alkaloids and Phenols Compounds extracted from black pepper Piper nigrum against some pathogenic fungi Jornal of B R. (2015); 9(2): 46-54.

42. Hammadi SY, Hussein AS, Majeed DM, Dheeb BI, Ismail EN. RAPD and ISSR analyses of Saccharomyces cerevisiae isolates from different sources Jornal of BRC .(2019); 12(2): 40-50.

43. Hamoody AHM, Abood JN, Dheeb BI. The synergistic effect of fungus filter Aspergillus terreus and aqueous extract of Fucus vesiculosus on some growth characteristics of the ocimum basilicum and its content of heocimumbasilicum and itscontentof active substances EurasiaJBiosci14,161$166 .(2020) ; 14: 161-166$.

44. Hashim SS, Shawkat MS. Protective And Creative Effects of Panax ginseng Aqueous Crude Extract in Histopathological Changes of BALB/c Mice Exposed to Aflatoxins. Egyptian Academic Journal of Biological Sciences, D. Histology and Histochemistry. (2016); 8(1): 15-24.

45. Al-Jaff DAA, Hashim SS, Al-Halbosy MMF. Cytotoxic Effects of Some Medical Plant Extract Against Cancer Cell Line Using Tissue Culture Technique. Research journal of pharmaceutical biological and chemical sciences. (2018); 9(1): 876-881. 